\title{
"The influence of corporate governance characteristics on profitability of Indian firms: An empirical investigation of firms listed on Bombay Stock Exchange"
}

\begin{tabular}{|c|c|}
\hline AUTHORS & 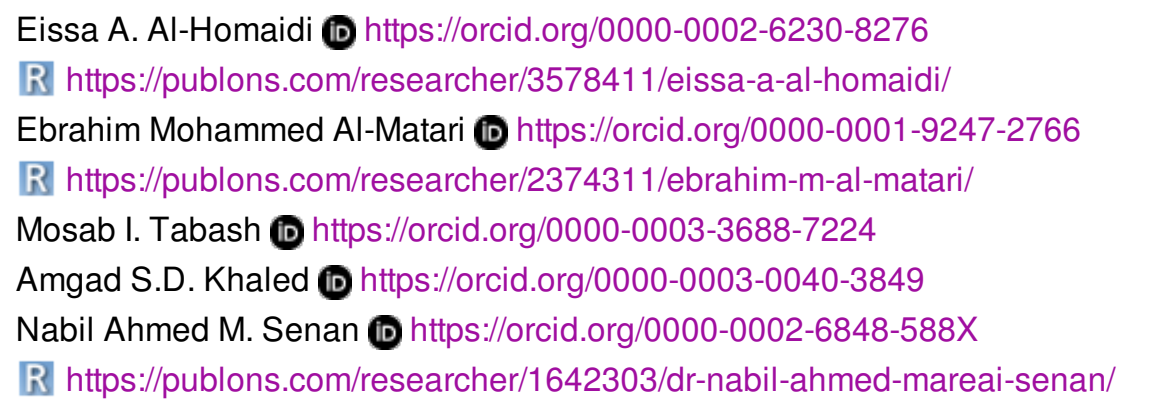 \\
\hline ARTICLE INFO & $\begin{array}{l}\text { Eissa A. Al-Homaidi, Ebrahim Mohammed Al-Matari, Mosab I. Tabash, Amgad } \\
\text { S.D. Khaled and Nabil Ahmed M. Senan (2021). The influence of corporate } \\
\text { governance characteristics on profitability of Indian firms: An empirical } \\
\text { investigation of firms listed on Bombay Stock Exchange. Investment } \\
\text { Management and Financial Innovations, 18(1), 114-125. } \\
\text { doi:10.21511/imfi.18(1).2021.10 }\end{array}$ \\
\hline DOI & http://dx.doi.org/10.21511/imfi.18(1).2021.10 \\
\hline RELEASED ON & Friday, 05 February 2021 \\
\hline RECEIVED ON & Saturday, 14 November 2020 \\
\hline ACCEPTED ON & Monday, 25 January 2021 \\
\hline LICENSE & $\begin{array}{l}(c) \text { EY } \\
\text { This work is licensed under a Creative Commons Attribution } 4.0 \text { International } \\
\text { License }\end{array}$ \\
\hline JOURNAL & "Investment Management and Financial Innovations" \\
\hline ISSN PRINT & $1810-4967$ \\
\hline ISSN ONLINE & $1812-9358$ \\
\hline PUBLISHER & LLC "Consulting Publishing Company "Business Perspectives" \\
\hline FOUNDER & LLC "Consulting Publishing Company "Business Perspectives" \\
\hline
\end{tabular}

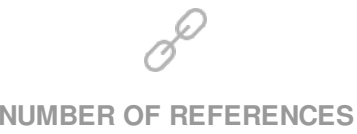

62
NUMBER OF FIGURES

1
NUMBER OF TABLES

5

(C) The author(s) 2021. This publication is an open access article. 


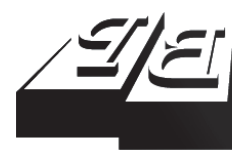

\section{BUSINESS PERSPECTIVES}

LLC "CPC "Business Perspectives" Hryhorii Skovoroda lane, 10, Sumy, 40022, Ukraine www.businessperspectives.org

Received on: $14^{\text {th }}$ of November, 2020 Accepted on: $25^{\text {th }}$ of January, 2021 Published on: $5^{\text {th }}$ of February, 2021

(ㄷ) Eissa A. Al-Homaidi, Ebrahim Mohammed Al-Matari, Mosab I. Tabash, Amgad S.D. Khaled, Nabil Ahmed M. Senan, 2021

Eissa A. Al-Homaidi, Ph.D., Research Scholar, Faculty of Commerce, Aligarh Muslim University, Aligarh, India.

Ebrahim Mohammed Al-Matari, Associate Professor of Accounting, College of Business, Jouf University, Kingdom of Saudi Arabia; Faculty of Commerce and Economics, Amran University, Yemen.

Mosab I. Tabash, Ph.D., Assistant Professor, College of Business, Al Ain University, UAE.

Amgad S.D. Khaled, Ph.D., Assistant Professor, Faculty of Management, Department of Management Information System, Al-Rowad University, Yemen.

Nabil Ahmed M. Senan, Associate Professor, Department of Accounting, College of Business Administration, Prince Sattam bin Abdul Aziz University, Kingdom of Saudi Arabia; Administrative Science College, Al-Baydha University, Yemen. (Corresponding author)
Eissa A. Al-Homaidi (India), Ebrahim Mohammed Al-Matari (Yemen),

Mosab I. Tabash (UAE), Amgad S.D. Khaled (Yemen), Nabil Ahmed M. Senan (Yemen)

\section{THE INFLUENCE OF CORPORATE GOVERNANCE CHARACTERISTICS ON PROFITABILITY OF INDIAN FIRMS: AN EMPIRICAL INVESTIGATION OF FIRMS LISTED ON BOMBAY STOCK EXCHANGE}

\begin{abstract}
This article aims to empirically examine corporate governance features and their association with Indian listed companies' profitability. Thirty-three listed firms are selected from the top 100 companies in India. Corporate governance is defined by two parts: board of directors (size, structure, diligence) and audit committee (size, structure, diligence). In contrast, the profitability of Indian listed firms is calculated by two indicators: return on assets (ROA) and earnings per share (EPS). The outcomes concerning ROA reveal that board diligence, size of audit committee, audit committee composition, diligence of audit committee, and size of a company has a significant relationship with ROA. In contrast, board size and board composition have an insignificant association with ROA. Concerning earnings per share (EPS) model, the results show that size of audit committee, audit committee composition, diligence of audit committee, and firm size have a significant relationship with EPS. In contrast, board size, board composition, and board diligence have an insignificant association with EPS. The results may be of benefit to those scholarly researchers, practitioners, and governors who are interested in exploring the quality of corporate governance practices in an emerging market such as India and its effect on firms' profitability
\end{abstract}

\section{Keywords} corporate governance, firms' profitability, ROA, EPS, panel data, India

\section{JEL Classification C23, L25, G34, G32}

\section{INTRODUCTION}

The main motivation of this study is to empirically investigate the association between corporate governance features and companies' profitability in a developing country, India. Specifically, this study checks the effect of corporate governance characteristics on firms' profitability (ROA and EPS) by Indian listed firms. The study strives to contribute to the discussion on whether excellent corporate governance can be seen as a prerequisite for a good firm (Haat et al., 2008) by reducing earnings management. Over the past two centuries, corporate governance is becoming a hot issue primarily created by corporate rumors and scams like Enron and WorldCom that have shaken both the corporate atmosphere and the confidence of investors. These reporting frauds are connected to poor accounts financial regulation (Berkman et al., 2009). There is a need to induce such norms that can minimize the scope of these scams. There is continuing discussion about whether excellent corporate governance leads to better company results. In this context, Black, Jang, and Kim (2006) reported that "high-governance companies have a high market value. In anticipation of improvement 
in companies' performance, the stock price could also react instantly to news suggesting better corporate governance. Companies with weak governance structures face more agency problems. Those companies' executives get more personal advantages due to weak governance structures" (Core, Holthausen, \& Larcker, 1999). There is no "unambiguous proof to suggest that better corporate governance increases firm profitability" (Klein et al., 2005). As a result, "investors are still skeptical about the presence of the link between good governance and profitability indices. For many professionals and scholars in the field of corporate governance, this remains their quest for the Holy Grail, the quest for the link between yields and governance" (Bradley, 2004).

Corporate Governance (CG) in India was originally controlled by the firms' Act of 1956, but recently the Indian Securities Exchange Board (SEBI) has to award the 2013 Companies Act and Clause 49 of the stock exchange listing as the main sources of Indian CG laws (Larson \& Pierce, 2015). Both laws have a huge effect on regulating CG issues in India (Agarwal, 2013; Jha \& Mehra, 2015; PwC, 2013; Sangwan, 2015). The amended clause 49 involves "(11) clauses on (1) shareholder rights, (2) board of directors (BOD), (3) audit committee, (4) appointment and remuneration committee, (5) subsidiary firms, (6) risk management, (7) associated party transaction, (8) disclosure, (9) CEO/CFO certification, (10) corporate governance report, (11) compliance report". Additionally, it has 4 annexes dedicated to "(1) data to be put before BOD, (2) quarterly compliance report format on CG, (3) proposed list of things to be included in the company's annual CG report, and (4) non-compulsory regulations. Regarding CG regulations on board size, structure, diligence, audit committee size, composition Clause 49 has distinct criteria for diligence".

Good corporate governance is a move that enables modus operandi to be developed and adhered to, resulting in corporate responsibility, structured ethical practices, and organizational accountability that heralds the handling of sufficient resources. The fact that CG is directly linked to a company's performance is not overemphasized. This realization has led to a range of empirical research into the relationship between corporate governance in ensuring enhanced organizational efficiency.

This investigation aims to seek the correlation between enterprise governance characteristics and profitability of 33 Indian listed companies during four years from 2011 to 2014 . The study achieves the main aim by two sub-objectives: first, to evaluate the influence of board of directors' effectiveness on profitability of Indian listed firms, second, to test the influence of audit committee effectiveness on profitability of Indian listed companies during the period of the study. However, it explores the influence of two corporate governance features as board of directors (size, structure, and diligence) and audit committee (size, structure, and diligence). This investigation is classified into two regression models from prior studies; ROA and EPS are indicators for measuring the profitability of Indian listed companies.

\section{LITERATURE REVIEW}

Many types of research used different indicators for examining firms' profitability, e.g., AL-Omar and AL-Mutairi (2015), Darayseh and Chazi (2018), Menicucci and Paolucci (2016), Mokni and Rachdi (2014), Zheng, Sarker, and Nahar (2018), Al-Homaidi et al. (2018), Almaqtari et al. (2018), and Al-Homaidi et al. (2019) applied ROA as a first indicator. In contrast, Waleed, Pasha, and Akhtar (2016) utilized EPS as a second indicator for testing firms' profitability in different countries. Said,
Zainuddin, and Haron (2009) demonstrated that only two factors were related to the scope of disclosure, explicitly public property ownership and audit working group. Group of the register of government management and audit is favorably and suggestively link with the rate of disclosure of corporate social obligation. Uchida, Ahmed, and Aabed (2011) indicated that governance has a beneficial but non-material connection with strong execution (return on assets). However, Cheema and Din (2013) revealed a beneficial connection between enterprise governance and company exe- 
cution had been identified. Adekunle and Maurice (2014) found a favorable and important connection between the structure of the board member and size of the board as autonomous factors and strong execution. The CEO position also has a beneficial connection with the firm's execution, but it is unimportant at $p<0.05$. Nevertheless, attention to ownership has a poor relationship with ROA but a beneficial connection with a profit margin (PM). The associations are not important at $5 \%$.

Dabor et al. (2015) examined the effect of enterprise governance features on profitability of the textile industry in Pakistan. The facts are set from the annual reports of the specific textile industry from 2005 to 2014 . The report's after-effects explain that enterprise governance and profitability demonstrate a beneficial connection with each other. This means that in the textile area. Shahwan (2015) stated a beneficial connection between CG practices and profitability. Haque and Arun (2016) recorded a favorable connection between the corporate governance quality of a firm and its valuation, although the relationship between corporate governance at the enterprise level and operational execution seems dubious. Herdjiono and Sari (2017) reported that board of directors' size has a favorable profitability result, while "the size of the audit committee, institutional proprietorship, and managerial proprietorship has no result on the profitability". According to Dzingai and Fakoya (2017), "outcomes designate a weak negative relationship between return on equity and board size and a weak but positive correlation between return on equity and board independence". Furthermore, there is a favorable but low association between equity returns and sales development, but an unfavorable and low connection between equity returns and company size. In contrast, Kapoor and Goel (2017) revealed that profitability is a significant variable, "as it moderates the connection between audit committee independence and the management of income". Managers of a profit-making business would have little need to change their income. Further, Arora (2012) suggested that enterprise governance has an important effect on company profitability. Mohan and Chandramohan (2018) indicated that the CG factor is the duality of the managing director and team composition, which had a substantial adverse effect on firms' profitability, whereas board structure disclosed no important effect on firms' profitability.

However, G.C (2016) demonstrated the size of the team, promoter control, and leverage a negative correlation with profitability. Kumar (2016) revealed a favorable connection for both factors. Similarly, Ahmad and Al-Homaidi (2018) revealed that the "audit group size and board size" had the largest disclosed proxies, whereas public ownership was the smallest exposure indicator for tourism companies. Jackling and Johl (2009) suggested that bigger board sizes have a beneficial influence on profitability, thus bolstering the opinion that increased display to the outside setting increases evaluate to multiple resources and has a favorable impact on profitability. Consistently, Raithatha and Bapat (2014) found that the average disclosure score was discovered to be $73 \%$, max and min are $100 \%$ and $46 \%$, respectively. The results "support agency theory in terms of tracking board function since board size is discovered to be important, but the research does not find any impact of board independence on disclosure". However, Ghosh (2006) revealed that, after managing various company-specific variables, larger boards tend to be dampened the effect on company profitability. Appendix A. presents summary of previous studies examined in different sectors in India.

Accordingly, this article aims to examine the impact of corporate governance mechanisms on firms' profitability of Indian listed firms. The research achieves the main objective by two sub-objectives:

1. To assess the impact of the effectiveness of the board of directors on the profitability of Indian listed companies;

2. To measure the impact of the effectiveness of the audit committee on the profitability of Indian listed companies during the study period.

This article bridges a divide in corporate governance and literature on profitability in India. Besides, the present research extends and contributes to previous research from different countries as it incorporates panel data from 33 Indian listed companies from 2011 to 2014 and uses various corporate governance factors comprehensively. 


\section{METHODOLOGY}

\subsection{Sample selection and model specification}

The data of the current study are collected from 33 Indian listed companies for a period of four years from 2011 to 2014 based on the following criteria: firstly, accessibility and availability of data for the period of research; secondly, non-financial firms; thirdly, there is a lack of studies that examined corporate governance and profitability from 2011 to 2015 in India. This investigation is based on secondary information collected from the published annual reports of Indian listed firms. This paper examines two elements of the features of "corporate governance: the board of directors (size, independence, and diligence) and the audit committee (size, independence, and diligence)". Firms' profitability is measured by two indicators (ROA and EPS).

Multiple regression was applied to identify the effect of corporate governance features on Indian listed firms' profitability. The review suggests the following model to check the business governance influence on the profitability of businesses defined by ROA and EPS:

$$
\begin{aligned}
& \text { Profitability }_{i t}=\alpha_{0}+\alpha_{1} \text { BSIZE }_{i t}+ \\
& +\alpha_{2} \text { BCOMP }_{i t}+\alpha_{3} \text { BDEL }_{i t}+ \\
& +\alpha_{4} \text { ACSIZE }_{i t}+\alpha_{5} \text { ACCOMP }_{i t}+ \\
& +\alpha_{6} \text { ACDEL }_{i t}+\alpha_{7} \text { FSIZE }_{i t}+\varepsilon_{i t} .
\end{aligned}
$$

$$
\begin{aligned}
& R O A_{i t}=\alpha_{0}+\alpha_{1} B S I Z E_{i t}+ \\
& +\alpha_{2} B C O M P_{i t}+\alpha_{3} B D E L_{i t}+ \\
& +\alpha_{4} A C S I Z E_{i t}+\alpha_{5} A C C O M P_{i t}+ \\
& +\alpha_{6} A C D E L_{i t}+\alpha_{7} F S I Z E_{i t}+\varepsilon_{i t} \\
& E P S_{i t}=\alpha_{0}+\alpha_{1} B S I Z E_{i t}+ \\
& +\alpha_{2} B C O M P_{i t}+\alpha_{3} B D E L_{i t}+ \\
& +\alpha_{4} A C S I Z E_{i t}+\alpha_{5} A C C O M P_{i t}+ \\
& +\alpha_{6} A C D E L_{i t}+\alpha_{7} C S I Z E_{i t}+\varepsilon_{i t}
\end{aligned}
$$

where Profitability $=R O A$ and EPS; $i$ relates to an individual firm; $t$ relates to year; $\alpha_{1}: \alpha_{8}$ are the determining coefficients of factors and $\varepsilon$ is term of mistake, and all other indicators as described in Table 1 and presented in Figure 1.

\subsection{Measurement of dependent variable}

Return on assets (ROA) is a ratio assessed by ("profit after tax to total assets") as a first indicator for measuring the firms' profitability used in previous investigations, e.g., Al-Homaidi et al. (2019), Menicucci et al. (2016), Zheng et al. (2018)loans, equity, deposits, economic growth, inflation and market capitalization on major profitability indicators i.e., return on asset (ROA, Al-Homaidi et al. (2019), Tabash et al. (2020), Al-Homaidi et al. (2020), adopted ROA as a first indicator for evaluating the profitability of firms.

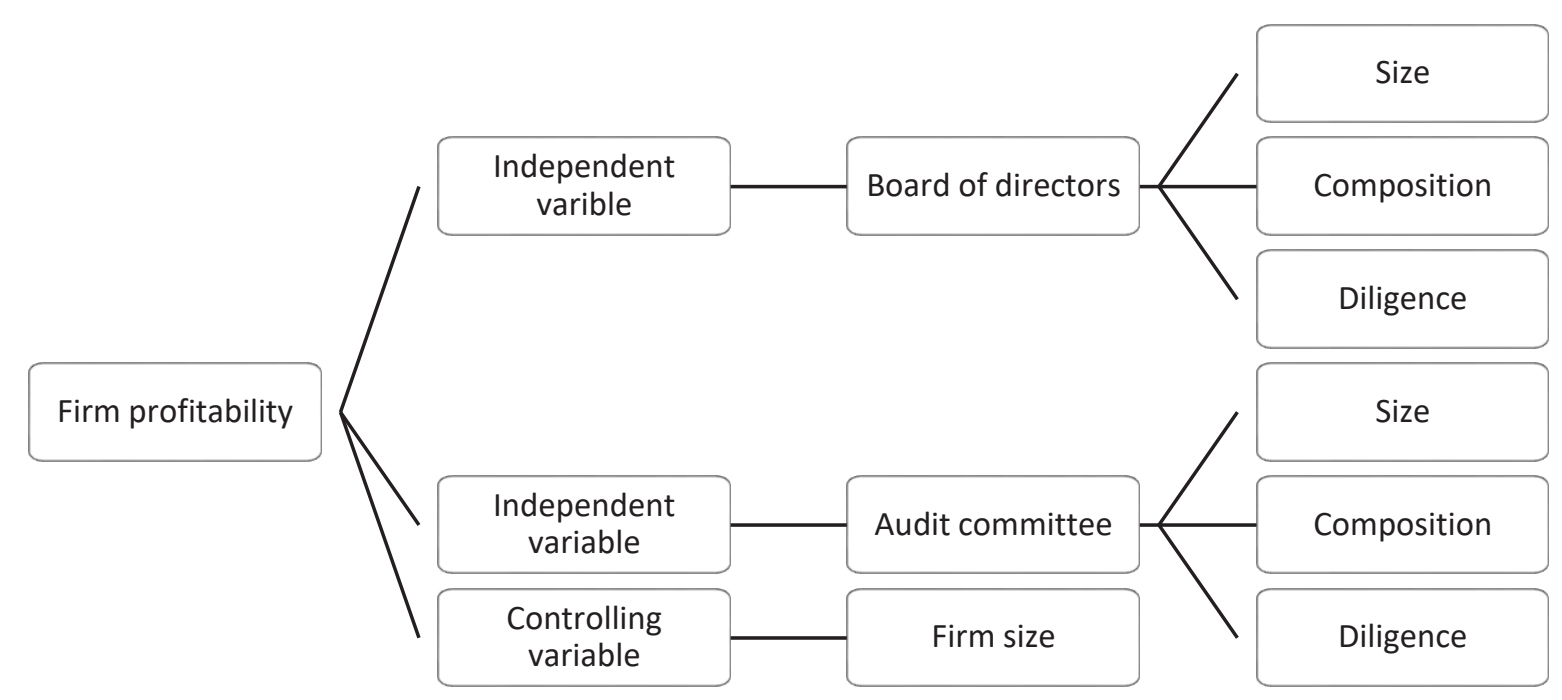

Figure 1. Study framework for all indicators 
Table 1. Measurement of variables

\begin{tabular}{|c|c|c|c|}
\hline Variable & Notation & Measurements & Sources \\
\hline \multicolumn{4}{|c|}{ Independent indicators } \\
\hline \multicolumn{4}{|c|}{ Board of directors' effectiveness } \\
\hline Size & BSIZE & Total no. of the members of board of directors & Annual reports \\
\hline Composition & BIND & $\begin{array}{l}\text { Number of independent members/total number of } \\
\text { members }\end{array}$ & Annual reports \\
\hline Diligence & BDLG & $\begin{array}{c}\text { Total number of conferences attended by all board } \\
\text { members/total amount of conferences conducted } \\
\text { throughout the year }\end{array}$ & Annual reports \\
\hline \multicolumn{4}{|c|}{ Audit committee effectiveness } \\
\hline Size & ACSZE & Total number of members of $A C$ & Annual reports \\
\hline Composition & ACIND & $\begin{array}{l}\text { Number of independent members/total number of } \\
\text { members }\end{array}$ & Annual reports \\
\hline Diligence & ACDLG & $\begin{array}{c}\text { Total number of conferences attended by all AC members/ } \\
\text { total amount of conferences conducted throughout the } \\
\text { year }\end{array}$ & Annual reports \\
\hline \multicolumn{4}{|c|}{ Controlling variables } \\
\hline Firm size & FSIZE & The logarithm of total assets & Annual reports \\
\hline \multicolumn{4}{|c|}{ Dependent variables (profitability) } \\
\hline Return on assets & ROA & Net profit after tax to total assets & Annual reports \\
\hline Earnings per share & EPS & Net profit after tax to numbers of equity shareholders & Annual reports \\
\hline
\end{tabular}

Earnings per share (EPS) is a ratio that can be measured by net profit after tax to numbers of equity shareholders as a second indicator for measuring firms' performance, (e.g., Abbas et al. 2014, Al-Homaidi et al. 2020, Al-Homaidi et al. 2019,Waleed, Pasha, and Akhtar 2016).

\subsection{Measurement of independent variables}

Corporate governance features measured by two parts, board of directors (size, independence, and diligence) and audit committee (size, independence, and diligence), were taken as important determinants of corporate governance. Table 1 summarizes the measurements of variables.

\section{RESULTS}

\subsection{Descriptive analysis}

Table 2 provides the outcomes of descriptive analysis for the research factors. The results show a mean, median, maximum, minimum, and Std. Dev. values of the variables. The average values of ROA and EPS are 10.126 and 42.424 and Std. Dev. values are 6.709 and 41.955, respectively, whereas the maximum value is 27.430 and 242.300 , and the minimum value is -0.710 and -1.460 , respectively. The BODSIZE, indicates the minimum value is 0.000 members of the board against the value is 25.000 as a maximum member in the board, with an average of 11.206 , the median value is 11.000 , and Std. Dev. of 2.870. The BODCOMP shows that the maximum value is 0.778 against value is -0.690 as a minimum value with an average value of 0.513 , the median value is 0.500 , and Std. Dev. value is 0.146 . The BODDIL shows the minimum value is -0.690 against value is 3.333 as a maximum value with an average value is 0.331 , the median value is 0.159 , and Std. Dev. value is 0.467 . The average value of ACSIZE, ACCOMP, and ACDELIG are 4.739, 0.741, and 0.164 , while minimum values are $3.000,0.500$, and 0.067 against value is $6.000,1.000$, and 0.317 as a maximum value with an average value are $4.739,0.741$, and 0.164 , median values are 5.000, 0.750 , and 0.146 , and Std. Dev. values are 0.903, 0.158 , and 0.063 , respectively. The FIRMSIZE reveals the minimum value is 7.209 against value is 12.237 as a maximum value with a mean value is 9.393, the median value is 9.306, and Std. Dev. value is 1.169 . 
Table 2. Descriptive analysis

\begin{tabular}{|c|c|c|c|c|c|c|}
\hline Variable & No. of obs. & Mean & Median & Maximum & Minimum & Std. Dev. \\
\hline ROA & 165 & 10.126 & 9.820 & 27.430 & -0.710 & 6.709 \\
\hline EPS & 165 & 42.424 & 27.730 & 242.300 & -1.460 & 41.955 \\
\hline BODSIZE & 165 & 11.206 & 11.000 & 25.000 & 0.000 & 2.870 \\
\hline BODCOMP & 165 & 0.513 & 0.500 & 0.778 & -0.690 & 0.146 \\
\hline BODDIL & 165 & 0.331 & 0.159 & 3.333 & -0.690 & 0.467 \\
\hline ACSIZE & 165 & 4.739 & 5.000 & 6.000 & 3.000 & 0.903 \\
\hline ACCOMP & 165 & 0.741 & 0.750 & 1.000 & 0.500 & 0.158 \\
\hline ACDELIG & 165 & 0.164 & 0.146 & 0.317 & 0.067 & 0.063 \\
\hline FIRMSIZE & 165 & 9.393 & 9.306 & 12.237 & 7.209 & 1.169 \\
\hline
\end{tabular}

\subsection{Correlation matrix and diagnostics of multicollinearity}

Table 3 reveals correlation assessment and multicollinearity diagnostics for current study factors. The results regarding ROA indicate that BODSIZE, ACSIZE, ACDELIG, and FIRMSIZE have a negative relationship with ROA, while BODCOMP, BODDEL, and ACCOMP have a positive correlation with companies' profitability calculated by ROA. Concerning EPS, the study reveals that BODSIZE, BODDEL, ACSIZE, ACDELIG, and FIRMSIZE positively correlate with company profitability assessed by EPS, while BODCOMP and ACCOMP have a negative association with profitability of Indian firms evaluated by EPS.

This research applied Variance Inflation Factor (VIF) test to check the multicollinearity problem. The results show no multicollinearity problem among the autonomous variables. All VIF values are below 5, which indicates that "multicollinearity problem among the independent variables is not present in this research" (see Table 3, panel B).

\subsection{Regression analysis}

Table 4 provides the outcomes of various regressions between independent and dependent factors. The adjusted $R$-squared model of pooled effects is 91 percent concerning ROA. This stated that independent proxies participate in about $91 \%$ of the ROA variation. The outcomes revealed that ACSIZE and FIRMSIZE significantly affect firms' performance at a $1 \%$ level, while BODDIL, ACCOMP, and ACDELIG have a significant influence on companies' profitability at the level of $10 \%$. BODSIZE and BODCOMP have an insignificant impact on firms' profitability calculated by ROA. The outcomes also suggest that BODSIZE, BODDIL, ACSIZE, and ACCOMP negatively associate with companies' profitability, while BODCOMP, ACDELIG, and FIRMSIZE have a positive impact on companies' profitability (ROA).

Concerning EPS, the adjusted $R$-squared of the random-effects model is $10 \%$. This indicated that independent factors lead to about $10 \%$ of the EPS variation. The results reveal that ACSIZE, ACCOMP,

Table 3. Correlation matrix and multicollinearity test

\begin{tabular}{|c|c|c|c|c|c|c|c|c|c|}
\hline Variable & ROA & EPS & BODSIZE & BODCOMP & BODDIL & ACSIZE & ACCOMP & ACDEL & FSIZE \\
\hline \multicolumn{10}{|c|}{ Panel A: Correlation matrix } \\
\hline $\mathrm{ROA}$ & 1.000 & & & & & & & & \\
\hline EPS & -0.059 & 1.000 & & & & & & & \\
\hline BODSIZE & -0.095 & 0.098 & 1.000 & & & & & & \\
\hline BODCOMP & 0.136 & -0.073 & 0.213 & 1.000 & & & & & \\
\hline BODDEL & 0.067 & 0.011 & 0.065 & 0.144 & 1.000 & & & & \\
\hline ACSIZE & -0.041 & 0.022 & -0.017 & 0.058 & 0.001 & 1.000 & & & \\
\hline ACCOMP & 0.277 & -0.051 & -0.118 & -0.054 & -0.057 & -0.362 & 1.000 & & \\
\hline ACDELIG & -0.133 & 0.267 & 0.074 & -0.039 & 0.239 & 0.099 & -0.178 & 1.000 & \\
\hline FIRMSIZE & -0.572 & 0.198 & -0.042 & -0.066 & -0.055 & 0.039 & -0.237 & 0.048 & 1.000 \\
\hline \multicolumn{10}{|c|}{ Panel B: Multicollinearity test } \\
\hline \multicolumn{3}{|c|}{ Variance Inflation Factor } & 1.041 & 1.053 & 1.027 & 1.162 & 1.262 & 1.063 & 1.067 \\
\hline
\end{tabular}


Table 4. Regression analysis

\begin{tabular}{|c|c|c|c|c|c|c|c|c|}
\hline \multirow{2}{*}{ Variable } & \multicolumn{4}{|c|}{ ROA } & \multicolumn{4}{|c|}{ EPS } \\
\hline & Coeff. & Std. Error & $\mathrm{t}$ & Prob. & Coeff. & Std. Error & $t$ & Prob. \\
\hline C & 0.672 & 0.416 & 1.617 & 0.109 & 0.560 & 0.526 & 1.065 & 0.289 \\
\hline BODSIZE & -0.152 & 0.196 & -0.773 & 0.441 & 0.092 & 0.119 & 0.777 & 0.439 \\
\hline BODCOMP & 0.176 & 0.192 & 0.917 & 0.361 & 0.092 & 0.110 & 0.835 & 0.405 \\
\hline BODDIL & -0.032 & 0.018 & -1.784 & $0.077^{*}$ & -0.019 & 0.057 & -0.340 & 0.735 \\
\hline D(ACSIZE) & -0.484 & 0.136 & -3.551 & $0.001^{* * *}$ & -0.029 & 0.015 & -1.938 & $0.055^{* *}$ \\
\hline ACCOMP & -0.358 & 0.193 & -1.853 & $0.066^{*}$ & -0.364 & 0.173 & -2.107 & $0.037^{* *}$ \\
\hline ACDELIG & 0.152 & 0.083 & 1.844 & $0.068^{*}$ & 0.858 & 0.311 & 2.755 & $0.007^{* * *}$ \\
\hline FIRMSIZE & 0.795 & 0.335 & 2.376 & $0.019 * * *$ & 0.854 & 0.436 & 1.958 & $0.053^{* *}$ \\
\hline$R$-squared & \multicolumn{4}{|c|}{0.934} & \multicolumn{4}{|c|}{0.144} \\
\hline Adjusted $R$-squared & \multicolumn{4}{|c|}{0.913} & \multicolumn{4}{|c|}{0.102} \\
\hline Durbin-Watson stat & \multicolumn{4}{|c|}{1.293} & \multicolumn{4}{|c|}{1.373} \\
\hline F-statistic & \multicolumn{4}{|c|}{45.229} & \multicolumn{4}{|c|}{2.979} \\
\hline Prob(F-statistic) & \multicolumn{4}{|c|}{0.000} & \multicolumn{4}{|c|}{0.006} \\
\hline Hausman test & \multicolumn{4}{|c|}{0.000} & \multicolumn{4}{|c|}{0.633} \\
\hline
\end{tabular}

ACDELIG, and FIRMSIZE significantly associate with firms' performance defined by EPS, whereas BODSIZE, BODCOMP, and BODDIL have an insignificant association with the profitability of companies measured by EPS. The outcomes also show that BODSIZE, BODCOMP, ACDELIG, and FIRMSIZE positively connect with companies' profitability, while BODDIL, ACSIZE, ACCOMP have a negative relationship with companies' profitability calculated by EPS. The results are similar to Mashayekhi and Bazaz (2008) who reported that board size had a favorable connection with companies' profitability (EPS). This impact is not strengthened by Cheema and Din (2013) who stat- ed that size of board has an insignificant influence on strong profitability (EPS).

Hausman test has been used to determine the correct method of analysis (fixed- or random-effects models). Regarding the ROA model, the Hausman test outcomes showed that since the $p$-value is less than $5 \%$ ( $p$-value $<0.05$ ), and the fixed-effects model is better than the random-effects model. In the case of the EPS experiment, however, the Hausman test results showed that the random-effects model experiment is more appropriate than the fixed-effects model because the $p$-value is more than $5 \%$ ( $p$-value $>0.05)$.

\section{CONCLUSION}

This article explores the association between corporate governance features and profitability of Indian listed companies. This investigation is based on secondary information collected from the published annual reports of Indian listed firms. Concerning ROA, the outcomes show that board's diligence, size of the audit committee, structure of the audit committee, audit committee's diligence, and size of the company have an important relationship with ROA. In contrast, the size of the board and the composition of the board have an insignificant association with return on assets (ROA). Concerning the EPS model, the results show that the size of the audit committee, the structure of the audit committee, the diligence of the audit committee, and the size of the company have an important relationship with EPS. In contrast, the size of the board, the composition of the board and the diligence of the board have an insignificant relationship with EPS. This investigation expands current literature, particularly in the Indian context, by examining companies' profitability concerning corporate governance characteristics adopted.

\section{AUTHOR CONTRIBUTIONS}

Conceptualization: Ebrahim Mohammed Al-Matari.

Data curation: Ebrahim Mohammed Al-Matari, Amgad S.D. Khaled. 
Formal analysis: Ebrahim Mohammed Al-Matari, Amgad S.D. Khaled.

Funding acquisition: Eissa A. Al-Homaidi, Amgad S.D. Khaled.

Methodology: Eissa A. Al-Homaidi, Amgad S.D. Khaled, Nabil Ahmed M. Senan.

Project administration: Nabil Ahmed M. Senan.

Resources: Mosab I. Tabash, Nabil Ahmed M. Senan.

Software: Ebrahim Mohammed Al-Matari, Mosab I. Tabash.

Supervision: Ebrahim Mohammed Al-Matari, Mosab I. Tabash.

Validation: Mosab I. Tabash.

Writing - original draft: Eissa A. Al-Homaidi.

Writing - review \& editing: Eissa A. Al-Homaidi, Nabil Ahmed M. Senan.

\section{REFERENCES}

1. Abbas, Q., Hunjra, A. I., Azam, R. I., Ijaz, M. S., \& Zahid, M. (2014) Financial performance of banks in Pakistan after Merger and Acquisition. Journal of Global Entrepreneurship Research, 4(1), 1-15. https://doi.org/10.1186/ s40497-014-0013-4.

2. Adekunle, S. A., \& Maurice, E. (2014). Corporate governance and financial performance of selected Quoted companies in Nigeria. European Journal of Business and Management, 6(9), 53-60. Retrieved from https://www.researchgate.net/ publication/290814265_Corporate Governance_and_Financial_Performance_of_Selected_Quoted_Companies_in_Nigeria

3. Agarwal, A. K. (2013). Corporate governance: financial regulators and courts need to be on the same page (W.P. No. 2013-03-03). Retrieved from http://hdl.handle. net/11718/11416

4. Ahmad, A., \& Al-Homaidi, E. A. (2018). Disclosure of corporate governance practices in Indian tourism companies. International Journal of Research, 05(15), 660-678. Retrieved from https://www.academia.edu/38537830/Disclosure_of_ Corporate_Governance_Practices_ in_Indian_Tourism_Companies.

5. Al-Homaidi, E. A., Ahmad, A., Khaled, A. S. D., \& Qaid, M. M. (2019). External factors and banks' performance: An empirical examination of commercial banks listed on Bombay Stock Exchange (BSE). International Journal of Emerging Technologies and Innovative Research, 6(6), 368-371. Retrieved from http://www.jetir.org/ papers/JETIR1907T24.pdf
6. Al-Homaidi, E. A., Almaqtari, F. A. Ahmad, A., \& Tabash, M. (2019). Impact of corporate governance mechanisms on financial performance of hotel companies: Empirical evidence from India. African Journal of Hospitality, Tourism and Leisure, 8(2), 1-21. Retrieved from https://www.ajhtl. com/uploads/7/1/6/3/7163688/article_31_vol_8_2_2019_uae.pdf

7. Al-Homaidi, E. A., Almaqtari, F. A., Yahya, A. T., \& Khaled, A. S. D. (2020). Internal and external determinants of listed commercial banks' profitability in India: dynamic GMM approach. International Journal of Monetary Economics and Finance, 13(1), 34-67. https://doi.org/10.1504/ ijmef.2020.10025082

8. Al-Homaidi, E. A., Tabash, M. I., \& Ahmad, A. (2020). The profitability of islamic banks and voluntary disclosure: empirical insights from Yemen. Cogent Economics \& Finance, 8(1), 1-22. https://doi.org/10.1080/2 3322039.2020 .1778406

9. Al-Homaidi, E. A., Tabash, M. I., Farhan, N. H., \& Almaqtari, F. A. (2019). The determinants of liquidity of Indian listed commercial banks: A panel data approach. Cogent Economics \& Finance, 7(1), 1-20. https://doi.org/1 0.1080/23322039.2019.1616521

10. Almaqtari, F. A., Al-Homaidi, E. A., Tabash, M. I., \& Farhan, N. H. (2018). The determinants of profitability of Indian commercial banks: A panel data approach. International Journal of Finance \& Economics, 24(1), 168-185. https:// doi.org/10.1002/ijfe.1655
11. Al-Matari, E. M. (2019). Do characteristics of the board of directors and top executives have an effect on corporate performance among the financial sector? Evidence using stock. Corporate Governance, 20(1), 16-43. https:// doi.org/10.1108/CG-11-2018-0358

12. Al-Matari, E. M., \& Mgammal, M. H. (2019). The moderating effect of internal audit on the relationship between corporate governance mechanisms and corporate performance among Saudi Arabia listed companies. Contaduria y Administracion, 64(4). https://doi.org/10.22201/ FCA.24488410E.2020.2316.

13. Al-Matari, E. M., Al-Swidi, A. K., \& Fadzil, F. H. B. (2014). Audit committee characteristics and executive committee characteristics and firm performance in Oman: empirical study. Asian Social Science, 10(12). https://doi.org/10.5539/ass. v10n12p98

14. Al-Matari, E. M., Al-Swidi, A. K., \& Faudziah, H. B. F. (2014). The effect on the relationship between board of directors' characteristics on firm performance in Oman: Empirical Study. Middle-East Journal of Scientific Research, 21(3), 556-574. https://doi.org/10.5539/ass. v10n11p149

15. AL-Omar, H., \& AL-Mutairi, A. (2008). Bank-specific determinants of profitability: The case of Kuwait. Journal of Economic and Administrative Sciences, 24(2), 20-34. https://doi. org/10.1108/10264116200800006 
16. Al-ahdal, W. M., Alsamhi, M. H., Tabash, M. I., \& Farhan, N. H. (2020). The impact of corporate governance on financial performance of Indian and GCC listed firms: An empirical investigation. Research in International Business and Finance, 51, 101083. https://doi. org/10.1016/j.ribaf.2019.101083Get

17. Arora, A. (2012). Corporate governance and firm performance in Indian pharmaceutical sector. Asian Profile, 40(6), 537-550. Retrieved from https://ssrn.com/ abstract $=2610488$

18. Arora, A., \& Sharma, C. (2016). Corporate governance and firm performance in developing countries: evidence from India. Corporate Governance, 16(2), 420436. https://doi.org/10.1108/CG-012016-0018

19. Bansal, N., \& Sharma, A. (2016). Audit committee, corporate governance and firm performance: empirical evidence from India. International Journal of Economics and Finance, 8(3), 103-116. https:// doi.org/10.5539/ijef.v8n3p103

20. Berkman, H., Cole, R. A., \& Fu, L. J. (2009). Expropriation through loan guarantees to related parties : Evidence from China. Journal of Banking 7 Finance, 33(1), 141-156. https://doi.org/10.1016/j.jbankfin.2007.11.001

21. Black, B. S., Jang, H., \& Kim, W. (2006). Does corporate governance predict firms' market values? evidence from Korea. The Journal of Law, Economics, \& Organization, 22(2), 366-413. https://doi. org/10.1093/jleo/ewj018

22. Bradley, N. (2004). Corporate governance scoring and the link between corporate governance and performance indicators: in search of the Holy Grail. Corporate Governance: An International Review, 12(1), 8-10. https://doi.org/10.1111/j.14678683.2004.00338.x

23. Cheema, K. U. R., \& Din, M. S. (2013). Impact of corporate governance on performance of firms: A case study of cement industry in Pakistan. Journal of Business and Management Sciences,
1(4), 44-46. Retrieved from https:// mpra.ub.uni-muenchen.de/53202/

24. Companies Act 2013 setting new standards for corporate governance in India.

25. Core, J. E., Holthausen, R. W., \& Larcker, D. F. (1999). Corporate governance, chief executive officer compensation, and firm performance. Journal of Financial Economics, 51(3), 371-406. https://doi.org/10.1016/S0304405X(98)00058-0.

26. Dabor, A. O., Isiavwe, D. T., Ajagbe, M. A., \& Oke, A. O. (2015). Impact of corporate governance on firms' performance. International Journal of Economics, Commerce and Management, 3(6), 634-653. Retrieved from http://www.sciepub. com/reference/307832

27. Darayseh, M., \& Chazi, A. (2018). Bank specifics, economics environment, and agency theory: determinants of banking performance in GCC. The Journal of Developing Areas, 52(4), 199212. https://doi.org/10.1353/ jda.2018.0060.

28. Dwivedi, N., \& Jain, A. K. (2005). Corporate governance and performance of Indian firms: The effect of board size and ownership. Employee Responsibilities and Rights Journal, 17, 161-172. https://doi. org/10.1007/s10672-005-6939-5

29. Dzingai, I., \& Fakoya, M. B. (2017). Effect of corporate governance structure on the financial performance of Johannesburg Stock Exchange (JSE)-listed mining Firms. Sustainability, 9(6), 867. https://doi. org/10.3390/su9060867.

30. FSB. (2015). Thematic review on supervisory frameworks and approaches for SIBs. Retrieved from https://www.fsb.org/2015/05/ thematic-review-on-supervisoryframeworks-and-approaches-forsibs/

31. GC, S. B. (2016). Corporate governance and firm performance: Empirical evidence from India. Journal of Business and Management Research, 1(1). https:// ssrn.com/abstract $=3643713$

32. Ghosh, S. (2006). Do board characteristics affect corporate performance? Firm-level evidence for India. Applied Economics Letters, 13(7), 435-443. https://doi. org/10.1080/13504850500398617.

33. Haat, M. C., Raaman, H. R., \& Mahenthiran, S. (2008). Corporate governance, transparency and performance of Malaysian companies. Managerial Auditing Journal, 23(8), 744-778. https://doi. org/10.1108/02686900810899518_

34. Haque, F., \& Arun, T. G. (2016) Corporate governance and financial performance: an emerging economy perspective. Investment Management and Financial Innovations, 13(3-1), 228-236. https://doi.org/10.21511/imfi.13(31).2016.09

35. Herdjiono, I., \& Mega Sari, I. (2017). The Effect of corporate governance on the performance of a company. Some empirical findings from Indonesia. Central European Management Journal, 25(1), 33-52. https://doi.org/10.7206/jmba. ce.2450-7814.188

36. Jackling, B., \& Johl, S. (2009). Board structure and firm performance: Evidence from India’s Top Companies. Corporate Governance: An International Review, 17(4), 492 509. https://doi.org/10.1111/j.14678683.2009.00760.x

37. Jha, V. S., \& Mehra, V. (2015) Corporate governance issues, practices and concerns in the Indian context - a conceptual study. ICTACT Journal on Management Studies, 1(2), 93-102. https://doi. org/10.21917/ijms.2015.0014

38. Kandukuri, R. L., Memdani, L., $\&$ Babu, P. R. (2015). Effect of corporate governance on firm performance? A study of selected Indian listed companies. In J. W. Kensinger (Ed.), Overlaps of Private Sector with Public Sector around the Globe (pp. 47-64). https://doi. org/10.1108/S0196-3821201531.

39. Kapoor, N., \& Goel, S. (2017). Board characteristics, firm profitability and earnings management: Evidence from India. Australian Accounting Review, 27(2), 180-194. https://doi. org/10.1111/auar.12144

40. Karam Pal Narwal, \& Shweta Pathneja. (2016). Effect of bankspecific and governance- specific 
variables on the productivity and profitability of banks. International Journal of Productivity and Performance Management, 65(8), 1057-1074. https://doi.org/10.1108/ IJPPM-09-2015-0130

41. Klein, P., Shapiro, D., \& Young, J. (2005). Corporate governance, family ownership and firm value: the Canadian evidence. Corporate Governance: An International Review, 13(6), 769-784. https:// doi.org/10.1111/j.14678683.2005.00469.x

42. Kumar, S. (2016). Corporate governance and firm performance in Indian listed IT companies. International Journal of Core Engineering \& Management, 2(10), 219-230. Retrieved from http:// ijcem.in/archive/volume-2-issue10-january-2016/

43. Larson, M. J., \& Pierce, C. (2015). Board evaluations: insights from India and beyond. Retrieved from http://documents.worldbank.org/ curated/en/605221468001781423/ Board-evaluations-insights-fromIndia-and-beyond.

44. Lemma, T. T., \& Negash, M. (2013). Institutional, macroeconomic and firm-specific determinants of capital structure: The African evidence. Management Research Review, 36(11), 1081-1122. https://doi. org/10.1108/MRR-09-2012-0201.

45. Mashayekhi, B., \& Bazaz, M. S. (2008). Corporate governance and firm performance in Iran. Journal of Contemporary Accounting \& Economics, 4(2), 156-172. https://doi.org/10.1016/S18155669(10)70033-3

46. Menicucci, E., \& Paolucci, G. (2016). The determinants of bank profitability: empirical evidence from European banking sector. Journal of Financial Reporting and Accounting, 14(1), 86-115. https:// doi.org/10.1108/jfra-05-2015-0060

47. Mohan, A., \& Chandramohan, S. (2018). Impact of corporate governance on firm performance: Empirical evidence from India. International Journal of Research in Humanities, Arts and Literature, 6(2), 209-218. Retrieved from https://ssrn. com/abstract $=3133491$
48. Mokni, R. B. S., \& Rachdi, H. (2014). Assessing the bank profitability in the MENA region A comparative analysis between conventional. International Journal of Islamic and Middle Eastern Finance and Management, 7(3), 305-332. https://doi.org/10.1108/IMEFM-03-2013-0031.

49. Nandi, S., \& Ghosh, S. K. (2012). Corporate governance attributes, firm characteristics and the level of corporate disclosure: Evidence from the Indian listed firms Sunil. Decision Science Letters, 2, 45-58. https://doi.org/10.5267/j. dsl.2012.10.004

50. PwC. (2013). Companies Act 2013 key highlights and analysis. Retrieved from https://www.pwc. in/publications/publications-2013/ companies-act-2013-key-highlightsand-analysis.html_

51. Rani, D. M. S., \& Zergaw, L. N. (2017). Bank specific, industry specific and macroeconomic determinants of bank profitability in Ethiopia. International Journal of Advanced Research in Management and Social Sciences, 6(3), 74-96. Retrieved from https://www.indianjournals.com/ijor.aspx?target=ijo r:ijarmss\&volume $=6 \&$ issue $=3 \&$ art icle $=005$

52. Sangwan, S. (2015). Framework of corporate governance: Issues and challenges. International Journal of Applied Research, 1, 126-130. Retrieved from https://www.allresearchjournal.com/archives/2015/ vollissue2/PartC/1-2-1159-553.pdf

53. Schiniotakis, N. I. (2012). Profitability factors and efficiency of Greek banks. EuroMed Journal of Business, 7(2), 185-200. https://doi. org/10.1108/14502191211245606

54. Shahwan, T. M. (2015). The effects of corporate governance on financial performance and financial distress: Evidence from Egypt. Corporate Governance, 15(5), 1-9. http://dx.doi.org/10.1108/CG-112014-0140

55. Singh Sehgal, B. P. (2014). Emerging trends in corporate governance: legal issues and challenges in India (45 p.). Retrieved from https://www. amazon.com/Emerging-Trends-
Corporate-Governance-Challenges/ dp/9382823239.

56. Tabash, M. I., Al-Homaidi, E., Ahmad, A., \& Farhan, N. H. S. (2020). Factors affecting financial performance of Indian firms: an empirical investigation of firms listed on Bombay Stock Exchange. International Journal of Economic Policy in Emerging Economies, 13(2). https://doi.org/10.1504/ijepee.2020.10029685

57. Said, R., Zainuddin, Y. H., \& Haron, H. (2009). The relationship between corporate social responsibility disclosure and corporate governance characteristics in Malaysian public listed companies. Social Responsibility Journal, 5(2), 212-226. https://doi. org/10.1108/17471110910964496

58. Uchida, S., Ahmed, S. U., \& Aabed, A. (2011). Corporate governance and firm performance in the financial sector. Annual Review of Southeast Asian Studies, 52, 107-115. Retrieved from https://ssrn.com/ abstract $=2342565$

59. Waleed, A., Pasha, A., \& Akhtar, A. (2016). Exploring the impact of liquidity on profitability: evidence from banking sector of Pakistan. Journal of Internet Banking and Commerce, 21(3). http://dx.doi. org/10.2139/ssrn.2899817.

60. Wingard, H. C., \& Vorster, Q. (2011). Financial performance of environmentally responsible South African listed companies. Meditari Accountancy Research, 9(1), 313-332. Retrieved from https://hdl.handle. net/10520/EJC72604

61. Zampara, K., Giannopoulos, M., \& Koufopoulos, D. N. (2017). Macroeconomic and industryspecific determinants of Greek bank profitability. International Journal of Business and Economic Sciences Applied Ressearch, 10(1), 13-22. https://doi.org/10.25103/ ijbesar.101.02

62. Zheng, C., Sarker, N., \& Nahar, S. (2018). Factors affecting bank credit risk: An empirical insight. Journal of Applied Finance \& Banking, 8(2), 45-67. Retrieved from https://EconPapers.repec.org/RePEc:spt:apfiba:v: 8:y:2018:i:2:f:8_2_3 


\section{$\vec{N}$ APPENDIX A}

Table 1A. Some of prior studies in India

\begin{tabular}{|c|c|c|c|c|c|c|c|}
\hline \multirow{2}{*}{ No. } & \multirow{2}{*}{ Author } & \multirow{2}{*}{ Objective } & \multirow{2}{*}{ Variables } & \multicolumn{4}{|c|}{ Sample } \\
\hline & & & & Size & Period & Data & Methods \\
\hline 1 & $\begin{array}{l}\text { Dwivedi and } \\
\text { Jain (2005) }\end{array}$ & $\begin{array}{l}\text { To study the relationship between } \\
\text { corporate governance and firm } \\
\text { performance of Indian companies }\end{array}$ & $\begin{array}{l}\text { Tobin's Q, the board size, advertising intensity, R\&D intensity, gross } \\
\text { fixed assets, current year ROCE, previous year ROCE, debt-equity ratio, } \\
\text { foreign shareholding, financial institution shareholding, directors' } \\
\text { shareholding, public shareholding, and trading activity }\end{array}$ & 367 firms & 1997-2001 & Secondary & $\begin{array}{l}\text { Descriptive } \\
\text { regression }\end{array}$ \\
\hline 2 & Ghosh (2006) & $\begin{array}{l}\text { To examine the association between } \\
\text { profitability and boards of non- } \\
\text { financial firms }\end{array}$ & $\begin{array}{l}\text { Return on assets, PERF, logarithm of size of board of directors, } \\
\text { logarithm of total assets netted for depreciation, cash flows, age of } \\
\text { the firm, leverage, percentage share price change, dummy variable } \\
\text { indicating uncertainty in the economic environment, and dummy } \\
\text { variable which assumes value } 1 \text { if a firm belongs to the private sector, } \\
\text { else zero; INDj1\%1 if a firm belongs to industry }\end{array}$ & 127 listed firms & 2003 & Secondary & Regression \\
\hline 3 & $\begin{array}{l}\text { Jackling and } \\
\text { Johl (2009) }\end{array}$ & $\begin{array}{l}\text { To investigate the relationship } \\
\text { between internal governance } \\
\text { structures and profitability of Indian } \\
\text { companies }\end{array}$ & $\begin{array}{l}\text { Return on assets, return on assets, Tobin's Q, number of outside } \\
\text { directors, outside directors, CEO chair, promoter CEO, CEO only } \\
\text { employee, powerful CEO, busyness - all directors, busyness - outside } \\
\text { directors, board size, board meetings, total assets, log of total assets, } \\
\text { leverage, capital expenditure to sales, research and development, and } \\
\text { firm age }\end{array}$ & Top listed firms & 2004-2006 & Secondary & $\begin{array}{l}\text { Descriptive } \\
\text { correlation } \\
\text { Regression }\end{array}$ \\
\hline 4 & Arora (2012) & $\begin{array}{l}\text { To examine the impact of corporate } \\
\text { governance on firm performance for } \\
\text { Indian firms for the period 2001-2010 }\end{array}$ & $\begin{array}{l}\text { Return on assets, adjusted Tobin's Q, board size, proportion of outside } \\
\text { directors, board activity intensity, institutional ownership, CEO-chair } \\
\text { duality, and firm age }\end{array}$ & $\begin{array}{l}150 \\
\text { pharmaceutical } \\
\text { firms }\end{array}$ & 2001-2010 & Secondary & $\begin{array}{l}\text { Descriptive } \\
\text { correlation } \\
\text { Regression }\end{array}$ \\
\hline 5 & $\begin{array}{l}\text { Raithatha and } \\
\text { Bapat (2014) }\end{array}$ & $\begin{array}{l}\text { To identify the impact of corporate } \\
\text { governance and ownership structure } \\
\text { on financial disclosures made by the } \\
\text { Indian firms }\end{array}$ & $\begin{array}{l}\text { Disclosure score, board size, board independence, board activeness, } \\
\text { board busyness, proportion of shares held by foreign promoters' } \\
\text { shareholders, proportion of shares held by institutional shareholders, } \\
\text { CEO duality, size, return on assets, leverage, quality of audit based on } \\
\text { audit firm size, and age }\end{array}$ & 325 listed firms & 2009-2010 & Secondary & $\begin{array}{l}\text { Descriptive } \\
\text { correlation } \\
\text { Regression }\end{array}$ \\
\hline 6 & $\begin{array}{l}\text { Kandukuri, } \\
\text { Memdani, and } \\
\text { Babu (2015) }\end{array}$ & $\begin{array}{l}\text { To assure importance of corporate } \\
\text { governance was recognized aftermath } \\
\text { the major corporate scandal and } \\
\text { regulators all over the world tightened } \\
\text { regulations }\end{array}$ & $\begin{array}{l}\text { Tobin's Q, Log of firm's age, Log of total firm's assets, and Corporate } \\
\text { Governance Index }\end{array}$ & 94 firms & 2011-2012 & Secondary & $\begin{array}{l}\text { Corporate } \\
\text { Governance } \\
\text { Index }\end{array}$ \\
\hline 7 & G.C. (2016) & $\begin{array}{l}\text { To analyze inter-linkages between } \\
\text { corporate governance, ownership } \\
\text { structure, capital structure, and firm } \\
\text { performance in India }\end{array}$ & $\begin{array}{l}\text { Market to book value, Tobin's Q, board independence, board size, board } \\
\text { committees, remuneration, promoter shareholding, return on assets, } \\
\text { leverage, ownership structure, corporate governance, firm size, firm } \\
\text { age, market performance, operating performance, and industry dummy }\end{array}$ & $\begin{array}{l}\text { CNX Nifty } \\
\text { companies }\end{array}$ & 2008-2012 & Secondary & Regression \\
\hline 8 & Kumar (2016) & $\begin{array}{l}\text { To examine the relationship between } \\
\text { corporate governance and firm } \\
\text { performance in Indian listed IT } \\
\text { companies }\end{array}$ & Return on assets, board size, board independence, and board diversity & $\begin{array}{l}\text { All IT listed } \\
\text { companies }\end{array}$ & $2008-2011$ & Secondary & $\begin{array}{l}\text { Descriptive } \\
\text { regression }\end{array}$ \\
\hline
\end{tabular}




\begin{tabular}{|c|c|c|c|c|c|c|c|}
\hline \multirow{2}{*}{ No. } & \multirow{2}{*}{ Author } & \multirow{2}{*}{ Objective } & \multirow{2}{*}{ Variables } & \multicolumn{4}{|c|}{ Sample } \\
\hline & & & & Size & Period & Data & Methods \\
\hline 9 & $\begin{array}{l}\text { Arora and } \\
\text { Sharma (2016) }\end{array}$ & $\begin{array}{l}\text { To examine the impact of corporate } \\
\text { governance on firm performance for a } \\
\text { large representative sample }\end{array}$ & $\begin{array}{l}\text { Return on assets, return on equity, net profit margin, Tobin's Q, stock } \\
\text { returns, square of board size, square of proportion of outside directors, } \\
\text { square of board meetings, chief executive officer duality, institutional } \\
\text { ownership }\end{array}$ & 20 industries & 2001-2010 & Secondary & $\begin{array}{c}\text { GMM } \\
\text { Regression }\end{array}$ \\
\hline 10 & $\begin{array}{l}\text { Kapoor and } \\
\text { Goel (2017) }\end{array}$ & $\begin{array}{l}\text { To explore the association between } \\
\text { earnings management and specific } \\
\text { board characteristics and the firm's } \\
\text { profitability in the Indian context }\end{array}$ & $\begin{array}{l}\text { Dechow and Dichev (2002) model, board size, board independence, } \\
\text { board busy, board attendance, firm age, ratio of market value to book } \\
\text { value, leverage, firm size, profit, ABS EPS, AC size, AC independence, AC } \\
\text { attendance, operational performance of the firm, and firm age }\end{array}$ & 297 companies & 2006-2013 & Secondary & $\begin{array}{l}\text { Descriptive } \\
\text { regression }\end{array}$ \\
\hline 11 & $\begin{array}{l}\text { Mohan and } \\
\text { Chandramohan } \\
(2018)\end{array}$ & $\begin{array}{l}\text { To study the impact of corporate } \\
\text { governance on firm performance: } \\
\text { empirical evidence from India }\end{array}$ & $\begin{array}{l}\text { Return on equity, price to book ratio, board composition, board size and } \\
\text { CEO duality, financial leverage, asset turnover, and growth in sales }\end{array}$ & 30 firms & 2007-2016 & Secondary & $\begin{array}{l}\text { Descriptive } \\
\text { correlation } \\
\text { Regression }\end{array}$ \\
\hline 12 & $\begin{array}{l}\text { Ahmad and Al- } \\
\text { Homaidi (2018) }\end{array}$ & $\begin{array}{l}\text { To examine the disclosure of } \\
\text { corporate governance practice in } \\
\text { published annual reports of Indian } \\
\text { tourism companies }\end{array}$ & $\begin{array}{l}\text { Board of directors (size, composition, and diligence), audit committee } \\
\text { (size, composition, and diligence), ownership (government, institutional } \\
\text { and overseas) }\end{array}$ & 53 firms & 2013-2015 & Secondary & Frequency \\
\hline 13 & $\begin{array}{l}\text { Al-Homaidi, } \\
\text { Almaqtari, } \\
\text { Ahmad and } \\
\text { Tabash (2019) }\end{array}$ & $\begin{array}{l}\text { To examine the impact of corporate } \\
\text { governance mechanisms on financial } \\
\text { performance of Indian hotel } \\
\text { companies }\end{array}$ & $\begin{array}{l}\text { Return on assets, net interest margin, earnings per share, board of } \\
\text { directors (size, composition, and diligence), audit committee (size, } \\
\text { composition, and diligence), institutional ownership, and company size }\end{array}$ & 30 firms & $\begin{array}{l}2013-2014 \\
2015-2016\end{array}$ & Secondary & $\begin{array}{l}\text { Descriptive } \\
\text { correlation } \\
\text { Regression }\end{array}$ \\
\hline 14 & $\begin{array}{l}\text { Al-Matari and } \\
\text { Mgammal } \\
\text { (2019) }\end{array}$ & $\begin{array}{l}\text { To analyze the impact on the financial } \\
\text { performance of Saudi financial firms } \\
\text { of corporate governance mechanisms }\end{array}$ & $\begin{array}{l}\text { ROA, board size, board non-executive, audit committee size, audit } \\
\text { committee independence, risk committee size, risk committee } \\
\text { independence, internal audit size, internal audit education, internal } \\
\text { audit professional certificate, firm size, leverage and bank sector }\end{array}$ & 47 firms & 2014-2017 & Secondary & $\begin{array}{l}\text { Descriptive } \\
\text { correlation } \\
\quad \text { FGLS } \\
\text { regression }\end{array}$ \\
\hline 15 & $\begin{array}{l}\text { Al-Matari } \\
\text { (2019) }\end{array}$ & $\begin{array}{l}\text { To investigate the impact of board } \\
\text { of directors and top executive } \\
\text { characteristics on financial sector } \\
\text { corporate performance }\end{array}$ & $\begin{array}{l}\text { Tobin's Q, board size, non-executive board, board meeting, top } \\
\text { executive management size, professional certificate of top executive } \\
\text { management, experience of top executive management, accounting } \\
\text { experience of top executive management, firm size and leverage }\end{array}$ & 24 firms & 2011-2017 & Secondary & $\begin{array}{l}\text { Descriptive } \\
\text { correlation } \\
\quad \text { FGLS } \\
\text { regression }\end{array}$ \\
\hline 16 & $\begin{array}{l}\text { Al-Matari, } \\
\text { Al-Swidi, and } \\
\text { Fadzil (2014) }\end{array}$ & $\begin{array}{l}\text { To examine the connection between } \\
\text { the characteristics of committees, } \\
\text { audit committee and the executive } \\
\text { committee and firm results in Oman }\end{array}$ & $\begin{array}{l}\text { Tobin's Q, board size, board composition, board meeting, CEO tenure, } \\
\text { Ceo compensation, board change, the secretary on the board, the } \\
\text { legal counsel, audit committee size, audit committee independence, } \\
\text { audit committee meeting, the executive committee size, the executive } \\
\text { committee independence, the executive committee meeting, firm size } \\
\text { and leverage }\end{array}$ & 162 firms & 2011-2012 & Secondary & $\begin{array}{l}\text { Descriptive } \\
\text { correlation } \\
\text { Multiple } \\
\text { regression }\end{array}$ \\
\hline 17 & $\begin{array}{l}\text { Al-Matari, } \\
\text { Al-Swidi, and } \\
\text { Faudziah (2014) }\end{array}$ & $\begin{array}{l}\text { To analyze the impact of the } \\
\text { relationship between the board } \\
\text { of directors on the success of the } \\
\text { company in Oman }\end{array}$ & $\begin{array}{l}\text { ROA, board size, board composition, board meeting, CEO tenure, CEO } \\
\text { compensation, board change, the secretary on the board, the legal } \\
\text { counsel, firm size and leverage }\end{array}$ & 162 firms & 2011-2012 & Secondary & $\begin{array}{l}\text { Descriptive } \\
\text { correlation } \\
\text { Multiple } \\
\text { regression }\end{array}$ \\
\hline 18 & $\begin{array}{l}\text { Al-ahdal et al. } \\
(2020)\end{array}$ & $\begin{array}{l}\text { To analyzes the impact of corporate } \\
\text { governance mechanisms on the } \\
\text { financial performance of Indian and } \\
\text { GCC listed firms }\end{array}$ & $\begin{array}{l}\text { Return on equity, tobin'sq, board accountability, transparency and } \\
\text { disclosure, audit committee index, leverage, governance effectiveness, } \\
\text { industry dummies, country dummies }\end{array}$ & 53 companies & 2009-2016 & Secondary & $\begin{array}{l}\text { Descriptive } \\
\text { correlation } \\
\text { Multiple } \\
\text { regression }\end{array}$ \\
\hline
\end{tabular}

